FACTA UNIVERSITATIS

Series: Philosophy, Sociology, Psychology and History Vol. 19, № 2, 2020, pp. 109 - 124

https://doi.org/10.22190/FUPSPH2002109S

Original Scientific Paper

\title{
PUBLIC TELEVISION AND THE RETURN TO SOCIALIST YUGOSLAVIA: MEDIATIZED CULTURAL MEMORY AMONG POST-SOCIALIST GENERATIONS ${ }^{1}$
}

UDC 316.774:654.197

\author{
Nataša Simeunović Bajić, Marija Vujović \\ University of Niš, Faculty of Philosophy, \\ Department of Communicology and Journalism, Niš, Serbia
}

\begin{abstract}
This paper deals with four significant concepts and discourses in contemporary Serbian post-socialist culture: sacred space, cultural memory, mediatization and Yugoslavia. A cursory look at the contradictions of Yugoslav history and politics implies a broadening of the research perspectives and themes. Unfinished debates about positive and negative aspects of socialist Yugoslavia provide an opportunity to rethink television heritage and cultural memory from a temporal distance. Here, we will discuss one dimension of memorized sacred space: TV reruns on public television in Serbia. Particularly, the research focus is on TV series as authentic TV genre and cult television. The paper shows that a large number of reruns of Yugoslav TV series on public television contributes to the maintaining of cultural memory among post-socialist generations and construction of the distinctiveness of the local cultural identity.
\end{abstract}

Key words: Yugoslavia, cultural memory, mediatization, TV reruns, sacred space.

\section{INTRODUCTION}

The breakup of Yugoslavia brought many crucial changes in political and social life. However, these changes have become in some way more of an abstract thing. The past is a discursive field. It is not something given; rather, it is a social construction. That is why a scholarly abstraction is often not a sufficient resource for researchers to answer the question of how emotions and sacred spaces of memory deal with a contested past (Simeunović Bajić \& Vujović 2018). Therefore, we need further research on cultural memory of post-socialist

Received July 19, 2020 / Accepted August 30, 2020

Corresponding author: Nataša Simeunović Bajić

University of Niš, Faculty of Philosophy, Ćirila i Metodija 2, 18000 Niš, Serbia

E-mail: natasa.simeunovic.bajic@ filfak.ni.ac.rs

${ }^{1}$ The part of research results, which is base on this article, was presented on the 11th Central and Eastern

European Communication and Media Conference CEECOM, 30th May - 1st June 2018 in Szeged, Hungary. 
generations. These generations were born after the breakup of the former Yugoslavia. Their experience is burdened not only with their families' oral histories, and not only with the sociopolitical context, but also with the ways of cultural memory mediatization.

Yugoslavia does not exist anymore. It is a fact. It is the past. However, discourse related to Yugoslavia has been very vital in recent years. In everyday life we perceive symbols of the Yugoslav period: from the cult of enjoying the taste of Plazma biscuits, and keeping Fića cars, gramophone records, collecting photographs, boxes of cigarettes, evoking vacations spent at the Adriatic sea, playing Zemljopis (a game also called interesting geography) and lastiš (playing jump rope), to visiting The House of Flowers and other tourist destinations and to the creation of popular media shows, as well as watching old cartoons and films online. Yugoslav symbols are still evident in the post-socialist environment. They have become a true melting pot, a mixture of different elements which, through a positive symbolic frame, represent Yugoslavia as a sacred space of our cultural and media memory (Simeunović Bajić \& Vujović 2018).

Television makes up quite a significant communication space. But it is not just that. Television is a very significant generator of cultural memory. Since television was one of the most important elements of the bureaucratic socialist model of cultural policy in Yugoslavia, it cannot be neglected when it comes to conducting research. During the second half of the 20th century, it was a dominant medium of mass communication, which largely influenced the social development of Yugoslavia. However, even in the 21st century, television in Serbia still remains quite significant. We are particularly interested in the successor of Television Belgrade - Radio Television of Serbia (RTS) - and its role in the affirmation of the Yugoslav television heritage. Undoubtedly, Television Belgrade created new cultural values, but it is necessary to determine what the effects of the re-creation and re-presentation of the Yugoslav television memory are in the contemporary media space in Serbia. Has television become the new sacred space of mediatized cultural memory? The research will try to answer this question, as well. Therefore, the aim of this paper is to emphasize the importance and influence of television as a cultural memory generator for young people born after the dissolution of Yugoslavia. In order to demonstrate this, we conducted a survey among the young members of the post-Yugoslav generations.

\section{THEORETICAL BACKGROUND}

This paper deals with four significant concepts and discourses in contemporary Serbian post-socialist culture: sacred space, cultural memory, mediatization and Yugoslavia. In the first place, understanding of the term 'sacred' is connected with Mirca Eliade's seminal book The Sacred and the Profane and his way of thinking. Beginning with the conception of dichotomy between sacred and profane as "two modes of being in the world, two existential situations" (Eliade 1959, 14) there is obviously more interdisciplinary insight in the perception of the various forms of space where we live. Space has become a very important idea and viewpoint of empirical clarification in our understanding of the world. Space and the sacred are closely connected. Space has sacred characteristics which mean that "the sacred is pre-eminently the real, at once power, efficacity, the source of life and fecundity" (Eliade 1959, 28). Adopting the perspective of distinction between significant sacred and amorphous profane areas, sacred space has become an ontological argument. However, in the postmodern sense, sacred space can be seen as a social construction and a context of permanent discursive struggles. The meanings of the sacred and profane are changing. In recent times, Eliade's clear dichotomy has been blurred in 
accordance with the dynamics of global challenges. "Spatially speaking, unlike in Eliade's structuralist narrative, these aspects are not 'ontological givens', and thus are not necessarily confined to a self-bounded sacred space starkly opposed to profane space, but they can be articulated and sustained within the 'ordinary secular"' (della Dora 2010, 167). This ordinary secular implies almost everything. In recent times cultural memory can be seen as an experience of ordinary people and everyday life, reflected by leisure time, return to the past, identity politics or polarized social activities. At the conference Conceptualizing Sacred Space(s). Perspectives from the Study of Culture Doris Bachmann-Medick "concluded that sacredness of a place is - as a specific kind of aura - not inherent, but always mediated." This means that time and space are categories without which mediatization is not possible. More than that, however, cultural memory is immanent sacredness.

It is well-known that cultural memory is a core concept of Jan Assman. On the basis of Durkheim's and Halbvash's theories, Assman stated something very interesting: "Cultural memory reaches back into the past only so far as the past can be reclaimed as "ours." This is why we refer to this form of historical consciousness as ' $\mathrm{m}$ e $\mathrm{m}$ o r $\mathrm{y}$ ' and not just as knowledge about the past. Knowledge about the past acquires the properties and functions of memory if it is related to a concept of identity. While knowledge has no form and is endlessly progressive, memory involves forgetting" (Assman 2008, 113). This conclusion reflects two things: firstly, it highlights a difference between the cultural memory and historical knowledge, and secondly, it presents cultural memory as a process that always involves forgetting. However, what is the role of media in this process? What happens to cultural memory when the media operate in a highly discursive way? What does mediatization in the context of Yugoslav cultural memory mean? These questions identify a need for deeper research in this area and address media historicizing to make cultural memory more relevant. As a concept that refers to the key role of media in society, mediatization has become one of the central scholarly themes in the beginning of the 21 st century. "Mediatization is a term that, by its very structure, implies historical change: that is, there is something or someone that is becoming ever more "-ized" (Deacon and Stanyer 2014, 1036). Something that is becoming more mediatized is Yugoslav cultural memory. The history of this country is not so long, but it is very dynamic. Almost thirty years after the breakup, there are many questions remaining. In the vast current literature, much more attention has been paid to the dissolution of Yugoslavia then to the other aspects of the Yugoslav existence (see Eriksen 2002; Blitz 2006). To locate the topic of Yugoslavia in a broader field of research, authors who mainly come from former member states emphasize the importance of culture and everyday life (see Luthar and Pušnik 2010; Volčić 2007). Understanding the contradictions of Yugoslav history and politics requires the broadening of research perspectives and themes. Unfinished debates about positive and negative aspects of socialist Yugoslavia provide an opportunity to rethink cultural heritage and cultural memory from a temporal distance. We all know - Yugoslavia does not exist anymore. However, there are a lot of stories, texts, images and memories about this country. In many mediatized ways, Yugoslavia is still visible to the contemporary audience.

\section{METHODOLOGY}

This research will try to point out what the characteristics of mediatized sacred space and TV popular images of Yugoslav cultural memory are. Here, we will discuss one dimension of memorized sacred spaces: TV reruns. In order to do that, we will use historical, narrative and discursive analysis. Moreover, a questionnaire with closed-ended and open- 
ended questions was used in this paper in order to determine what aspects of TV series as producers of cultural memory are recognized by young people.

Historical analysis helps us understand the past. The better we understand it, the easier it will be for us to organize the present and imagine the future. Those are the simplest clarifications of the need to take this type of analysis into consideration. "Since all the facts cannot be mobilized in any written history because of their great number, there is some principle on which selection from these facts is based. Such a principle is a tool of a historical analysis" (Quigley 1961). The principle of selection in our paper is based on the importance of studying Television Belgrade as the biggest Yugoslav television production. Within that, the selection is further narrowed down to television series as an authentic television genre and specific discursive creation (see Simeunović Bajić 2015). That is why we need discursive analysis, because it connects the text (in this case, TV series) and the context (the social-political period in which the series were made and in which their reruns were aired) in the most adequate way. "Discourses may be identified by a specific terminology, as is found in scientific discourses. But a discourse is also characterized by the way it combines various concepts, and how certain concepts are attributed a central role" (Ifversen 2003, 65). The discovery of key concepts in this field will help us determine the consequences of discursive practices in the formation of cultural memory. Since television shows use narration, we also require narrative analysis. A questionnaire filled out by young people born after the breakup of the former Yugoslavia made a significant contribution to the study of post-socialist cultural memory. The questionnaire contained the following groups of questions:

1. Regarding Yugonostalgia (Do you feel any kind of connection with the former Yugoslavia?; To what extent do you agree with the statement - we are still nostalgic for the former Yugoslavia even though it has not existed for a long time?;

2. Regarding TV series and cultural memory: Do you watch reruns of former Yugoslavia TV series on public television? Do you watch all of the episodes of these TV series or rather parts of the series online?; To what extent do you agree with the statement? - I prefer to watch the domestic TV series on public television (reruns) because I like them more than the foreign TV shows (American, Turkish, Indian, Latin American/Spanish). To what extent do you agree with the statement? - Reruns of old domestic TV series produced by TV Belgrade are necessary and desirable; To what extent do you agree with the statement? Yugoslav TV series are an important part of the cultural memory of generations born after the breakup of Yugoslavia;

3. Regarding the TV series chosen for reruns: Which of these domestic TV series have you never heard of? What grade would you give to the TV series: Više od igre [English: More than a game], Otpisani [English: The Sacrificed]? Kamiondžije [English: Truckers], Vruć vetar [English: Hot Wind], Građani sela Luga [English: Citizens of the Village Lug]? What TV series would you say is the greatest of all time?

4. Regarding cult TV and authenticity: What is it that makes Yugoslav TV series authentic? Can these series be considered cult shows?

5. Comments and observations

It was conducted in four cities in Serbia and surrounding villages among high school students and university students. The cities are: Belgrade, Niš, Kraljevo, Novi Sad. Thus, it was ensured that the entire country was covered including the capital, the midland, the south of Serbia and the autonomous province of Vojvodina. 


\section{SOCIALIST TELEVISION AND YUGOSLAVIA}

We are still a long way from comprehensive conclusions about socialism from the perspective of post-socialist cultural memory and Yugonostalgia. Initially, Yugonostalgia was primarily spoken about only in media texts; however, this concept then became very relevant to researchers and academics. Many authors now discuss the topic even though they do not come from the former Yugoslavia, including dissertations being written about this concept (Chushak 2013). Authors most often link the emergence and spread of Yugonostalgia with dissatisfaction with the current socio-political situation (Bancroft 2009, Maksimović 2017; Spasić 2012). However, the connection between socialist television and Yugonostalgia has not been extensively analyzed. This concept is partly covered in the very significant books on socialist television by Aniko Imre (2016) and Sabina Mihelj and Simone Huxtable (2018), but another perspective is necessary as well: the influence of socialist television on the preservation of Yugonostalgia among the post-socialist generations. That is why our knowledge about socialist television is still incomplete and fragmented. Side by side with this complex thematic scope are many misreadings and misinterpretations due to a lack of deeper understanding. While much of the study of television has focused on Western societies, socialist television became the focus of scholarly attention in the past several years. Western television has been researched in many perspectives, but socialist television has remained unexplored in the academic world. This is, the case with television in Yugoslavia. The research accent was put on Yugoslav wars and their consequences. However, as a significant cultural forum and a form of the evolution of soft socialism, TV in Yugoslavia deserves special attention. Not only that, but it is also a discursive field with many different representations and meanings. Post-war popular culture in Yugoslavia has developed in parallel with the rise of television technology and openness toward the West. Fortunately, there are a few good researchers in this area. For example, Sabina Mihelj concluded that "understanding socialist television is a key prerequisite for developing a truly global television history, and for revisiting some of the key debates about television as a cultural, political and economic formation" (Mihelj 2014, 7). Similarly, Dana Mustata said: "Situating socialist television through its full spectrum of lived experiences and social practices may not be enough. We also need to account for the fact that socialist television has simultaneously occupied conflicting social spaces, having performed simultaneously as part of state politics as well as part of everyday life, as part of history and as part of memory, as part of high culture and equally as part of popular culture" (Mustata 2014, 3). In socialist Yugoslavia, TV Belgrade was the biggest production center. Therefore, it implies huge amounts of audiovisual content. The Archives of Television Belgrade emerges as one of the largest in Europe. The director of the Archives, Mileta Kečina, said that if we could continuously, 24 hours a day, broadcast archival material, it would last for 20 years (Vuković 2009). These data bring us to conclusion that today's hype about socialist television is more than just fascination for the Yugoslav past. It is starting point for new research perspectives. One of them is certainly the attitude of the young generations towards television heritage, which will be discussed later on in this paper.

\section{THE HisTORY OF TELEVISION BELGRADE}

Regardless of the quite divided opinions on the success of Yugoslavia on the cultural, economic, political and social plane, the fact that television as a social and state institution left a deep mark on the history of the 20th century is unquestionable. That is 
certainly confirmed by the aforementioned facts. Even though there were as many television channels as republics and provinces, Television Belgrade had the biggest production and, it is safe to say, left the most valuable cultural mark. The broadcasting of a joint experimental program, created via the participation of Television Belgrade, Television Zagreb and Television Ljubljana, started on the eve of the greatest Yugoslav holiday (November 29th, Republic Day). The joint domestic program was broadcast for three days (Wednesday, Saturday, Sunday), while the foreign program was broadcast for another three days (Monday, Tuesday, Thursday). Television Belgrade was supposed to ensure 30 shows without transmission. Essentially, the equal participation of all three television channels in broadcasting the program was planned. However, in the following years, it was proven that Television Belgrade was dominant in the quantity of the produced and broadcast programs (see Simeunović Bajić 2015). The mimicking of the approach and organization of the BBC was quite important for its development. The earliest report on the ratings of the television was created in the Material on Quantitative Surveys on Monitoring Television Program, in June 1960 (Simeunović Bajić, Josifović and Senić 2013). Since the very start, they took care about the representation of various programs: news, cultural, educational, musical, film, series, sports and children's programs. Actually, Television Belgrade adhered to the application of three functions of television: informative, educational and entertaining. In 1961, the channel conquered all television genres, while the program reached significant scope. They even reported on the solar eclipse and the First Conference of the Non-Aligned Movement. The channel started introducing program in color in 1971, and the main news program Dnevnik 2 shifted from $8 \mathrm{pm}$ to $7: 30 \mathrm{pm}$ in 1974. That show has been broadcast at that same time to this day. Between 1971 and 1978, all conditions for "equal cooperation with the most developed television channels in the world" were created (see Simeunović Bajić 2015). The cooperation was quite fruitful, and Television Belgrade became recognizable in almost the entire world. The cultural ties formed during the era of the Non-Aligned Movement certainly contributed to that. In 1986, the broadcasting of the Morning Show started, and the Third Channel started in 1986. In 2002, Radio Television of Serbia started working. Its resources were damaged during the NATO bombing and the change of the regime in Serbia in 1999 and 2000. After the reconstruction, reorganization and reestablishment of the new national television, RTS fought for first place on the list of television channels in Serbia for years, trying to maintain the quality of public television and ensure a greater audience at the same time (see Simeunović Bajić 2015).

\section{TV RERUNS AS PRESERVATIONS OF CULTURAL MEMORY}

In post-socialist Serbia in recent years we noted a trend of rerunning TV programs made by TV Belgrade. This trend is a characteristic of commercial as well as public television. The question we ask here is this: why are there still reruns of Yugoslav shows when it has already been three decades since the disintegration of Yugoslavia? There are two main reasons: the first reason is a pragmatic-commercial one: no national television production is copious enough to function solely on producing new programs without reruns; and the second attempts to conquer viewers' preferences of a social group which still cherishes cultural memory of Yugoslavia. Thus, TV discourse participates in the articulation of social practices in a complex post-socialist political context, thereby significantly affecting the mediatization of the meaning of Yugoslav cultural memory. That is no small contribution.

Commercial televisions mostly rerun (rebroadcast) comedies since the first selection is based on the entertaining function of television. The other line of selection represents 
rebroadcasting partisan war films which are meant to remind us that we used to live in socialist Yugoslavia, which was created after World War II.

The Serbian public broadcaster Radio Television of Serbia (RTS) reruns many other television formats, especially in the TV show Trezor (English: Treasure Vault) which is a truly valuable and precious re-presentation of the archive. It preserves and reminds people of the rich television heritage. However, Radio Television Serbia has most frequently rerun the television show Bolji život (English: A Better Life) which is considered to be the last, most significant TV series filmed in Yugoslavia. It was being filmed during the breakup period of the socialist system in Yugoslavia, but the audiences seem to believe that the Serbian social reality it depicts has not changed even after almost three decades.

Whatever the motive is for rerunning old TV shows and series, the fact is that Radio Television Serbia uses the reruns as mediatization in order to protect cultural heritage and to help it remain vital. Such media policy is becoming a part of cultural policy.

Today, the Radio Television of Serbia is the main producer of reruns. For example, RTS have been re-running and re-airing many popular films, TV series, and children's TV shows for the past two decades. Therefore, in one research about viewers' preferences, audience members said that there was too much advertizing, too many reality programs and also too many reruns on TV (Josifović and Senić 2011). Nevertheless, the fact that the mediatized field is very broad and, in some aspects contested, is characteristic for the meanings of this concept of 'too many reruns'. In other studies about reruns and the response of the audience to it, the data shows that viewers do watch TV reruns of programs broadcasted and aired in the former Yugoslavia, but they also want to watch reruns of children's programs, old talk shows, informative programs, travel and cooking shows (Simeunovic Bajić, Vesnić Alujević and Majdarević 2012).

\section{Cult TeleVision: The New Value of TV Series}

The notion of a cult implies something that has been, according to cultural value, deemed classical in recent times. This category spilled over from art history and sociology into media studies and is often used in television research:

"Cult television series have become synonymous with participative and distinctive culture: a pronounced taste for original versions and unseen episodes, an initiatory culture based on hyperknowledge of textual and paratextual elements, challenges to the domination of the written text and the strict distinction between major and minor arts, a claim of cultural independence for youth accompanied by a valorization of audiovisual elements that become the dominant elements of a new form of culture to be consecrated" (Gwenllian-Jones, Pearson 2004).

Compared to the theater, novels in sequels and film, to which television series owe certain elements, the biggest novelty of this genre is its harmonization with television production. That includes a new relation of the audience towards space and time, because the dynamics of airing shows requires the regular presence of a large number of viewers in front of the television set and it also requires allocation of their free time to find out what will happen next. From 1959 to 1995, a total of 109 domestic TV shows produced by Television Belgrade were filmed and broadcast. The number already speaks enough about the need to approach domestic TV series from a different angle, which will no longer be burdened with sharp criticism in line with the criteria of traditional sociology of culture. Judging by the few papers in Serbia in which domestic TV series are mentioned, it seems that researchers still do not 
recognize the significance of these television forms. TV series need to be recognized as an authentic television genre, and some television series should even be included in cult television. Research shows that between 2003 and 2013, the share of Yugoslav television production, aside from foreign and domestic, grew on public television between $4.4 \%$ and 20.1\% (Nielsen Audience Measurement 2013). The reruns of TV series created in the period 1970-1980 will be analyzed here: Kamiondžije (Truckers), Otpisani (The Sacrificed), Više od igre (More than a Game), Građani sela Luga (Citizens of the Village Lug) and Vruć vetar (Hot Wind). This period represents the 'golden age' of Television Belgrade, because the editorial teams of the film and television program were separated back then, instigating some type of creative competition (see Simeunović Bajić 2015). The data about the years in which these shows were rebroadcast are incomplete, because there is no official archive or fully available data. The data that follow have been collected at the RTS Centre for Research of Public Opinion, Programs and Auditorium: the TV series Građani sela Luga (Citizens of the Village Lug) was rebroadcasted in 2007, 2012 and 2019; the TV series Truckers was rebroadcasted in 1984, 2003, 2006, 2010, 2014, 2016, 2017; the TV series More than a Game was rebroadcast in 1979, 1988/1989, 1990, 2006, 2007, 2010, 2012, the TV series The Sacrificed was rebroadcasted in 1980, 1989, 1994, 2006, 2009, 2011, 2014, 2017, and TV series Hot Wind was rebroadcasted in 2009, 2010, 2011, 2015 and 2018.

The series Citizens of the Village Lug was broadcasted in 1972. Its characteristic qualities included rural motifs and people's humor. However, this series displays a dose of acrimony and bitterness in dealing with post-war themes of nationalization and industrialization, representing a sort of historical chronicle of the time. That is another proof of soft socialism, which still allowed irony concerning the state's project of urbanization and industrialization to permeate a television series. This is a story about misunderstandings between villagers and workers and the concept of turning the former group into the latter for the sake of a better Yugoslav life.

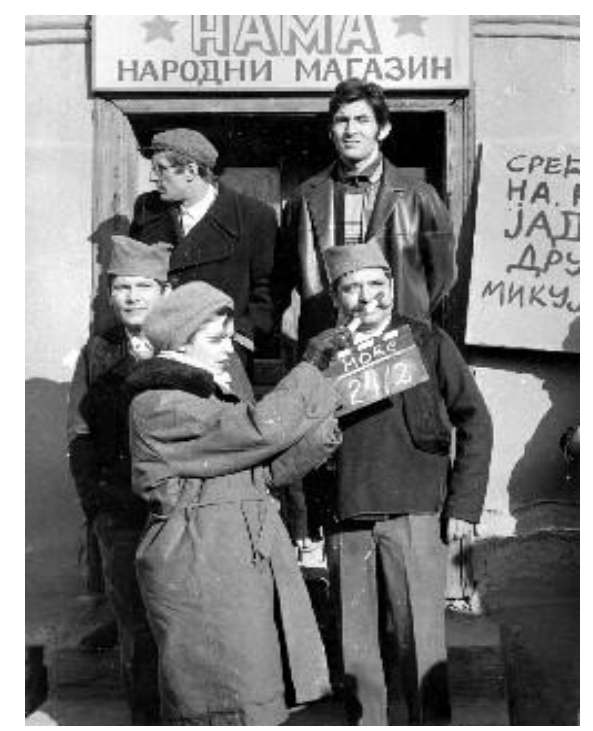

Fig. 1 From the set of the TV series Citizens of the Village Lug, S0004078, TV archive, http://tvarhiv.rts. rs/wwdok/full/S0004078.jpg 
The TV series Truckers premiered in 1973. In a humorous way, the show follows the adventures of two friends, Paja and Jare, who are trying to start a business, but they cannot seem to make it work. Dealing with the local culture environment, the nature of the common people and the images of the social margin, this series creates in the audience the receptiveness and emotional connection with the 'little man'. Even though it shows the socialist reality in a somewhat ironic way, at its core, it was not filmed to show the bad sides of socialism. The original intent of the author was to transfer the mosaic of everyday life stories. Folk music is one of the elements that connect the narrative world of the series and brings it closer to the lowest and least educated layers of society. Quips, proverbs and various folk sayings are also something that preserves the tradition of the rural world.

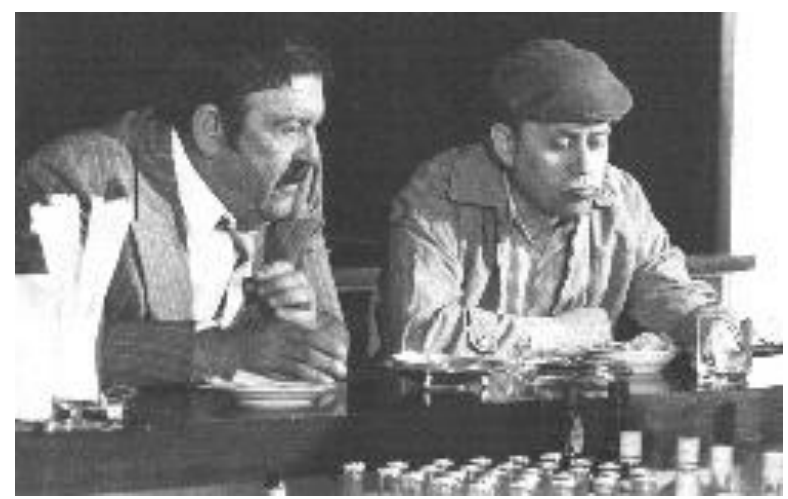

Fig. 2 A scene from the fifth episode of the series Truckers. The main characters in a kafana, S0000012, TV archive, http://tvarhiv.rts.rs/wwdok/Kasete.htm

Even though at first glance it seems that this television show, which is set in the city, is dominated by rural humor including folklore elements, in fact, after an in-depth analysis, criticism of the socialist system can be recognized.

The series The Sacrificed was broadcast in 1975 and it represents the first urban drama series about young people in occupied Belgrade. The series follows the operations carried out by a group of communist youths who become quite experienced saboteurs. They are on the German enemies' hit list and must be taken off the list. However, these young wellversed illegal heroes cause great damage to the German occupying forces by defending their hometown. Even though the Yugoslav partisan film as a special genre was used to remind the people of the achievements of the revolution, this is the first series that was supposed to remind the people of the significance of the fight against the occupier that was much stronger. Individual and collective morale reach their full potential. That is the socialist version of the fight between David and Goliath. It is not strength that is most important in the fight, but wisdom. This accentuates the significance of youth and, in this case, it is tied to wisdom. That way, the urban identity of resistance is visually represented, while the binary relation between black and white, good and evil, is symbolically established. The young saboteurs break prohibitions and find cracks in the order established by the occupiers. The meaning generative system of the series is based on the established scheme of discursive actions: violated order - chosen heroes that are affirmed every time - danger almost impossible righteous mission - satisfaction and appeasement - temporarily established order (Simeunović Bajić 2016). That is actually the similar formula that every fairytale 
follows. However, due to the aforementioned elements, the series has had quite a large audience in Serbia and other former Yugoslav republics for decades. It has surpassed genre conventions and the imposed an ideological condition about winning against the German enemy by becoming another valuable piece of television heritage.

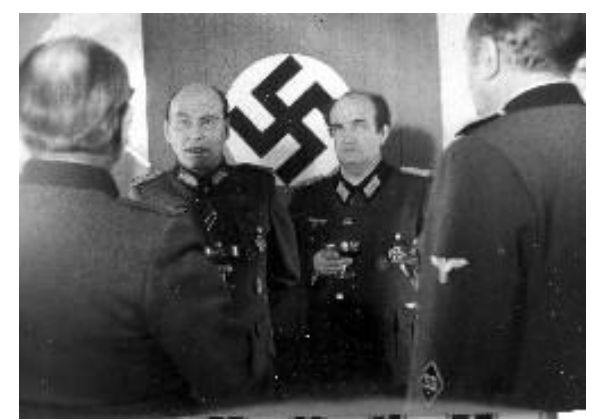

Fig. 3 Image of the Germans in The Sacrificed, TV archive, S0000605 http://tvarhiv.rts.rs/wwdok/Kasete.htm

Another series which deals with a righteous revolution is More than a Game, produced in 1976, but broadcasted in 1977 (see Simeunović Bajić 2015). However, it is not as direct as The Sacrificed. The Manichaean division between the black and white world was not made in such an obvious manner. The historic period of the represented story includes a whole decade before World War II. In it, the bourgeoisie is slowly disappearing, and a new, working, communist world is being built. The value of this series lies in the nuanced and artistically well-presented conflict between two ideologies. Another important element of this series is the fact that football was presented for the first time. It is not until much later, in the second decade of the $20^{\text {th }}$ century, that a series was made with the same title as the movie Montevideo, God Bless You! which once again dealt with the topic of football.

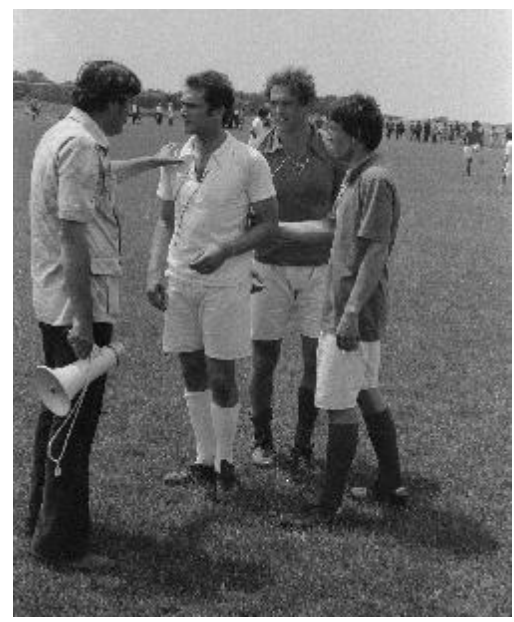

Fig. 4 From the set of the series More than a Game. Director Zdravko Šotra with actors Voja Brajović and Slobodan Đurić, S0041192, http://tvarhiv.rts.rs/wwdok/full/S0041192.jpg 
The last TV series selected for analysis was Hot Wind, filmed in 1979 and aired at the beginning of 1980. It shows the developmental path of a young man, who is trying to find his way in a socialist environment that is already suffering a gradual decline. Whatever he tries to do is not successful. He is financially supported by his family and close relatives. He seems spoiled and lazy. He is a hypochondriac. He likes to enjoy himself. He loves Greek music. However, he finds both the love of his life and the job of his life. He becomes a famous hairdresser. Therefore, the production of meaning concerning the attainable Yugoslav socialist dream - marriage, apartment, job - is now presented visually. It is interesting to mention the research conducted by Ana Maria Soresku Marinkovic on watching Yugoslav television shows in Romania - one interviewee even said that his friend and colleague was nicknamed after the character in this TV series - Shurda - and the "Timisoara Shurda" confirmed this in a later conversation (Soresku Marinković 2014, 34).

These series belong to what researchers call cult television (Gwenllian-Jones, Pearson 2004; Lavery 2010). A large number of reruns of Yugoslav TV series on public television contributes to maintaining cultural memory and the construction of the distinctiveness of local cultural identity, considering that people remember only the things they communicate on and things they can localize within the collective memory (Asman 2011). The imported series of big production companies certainly cannot influence the formation of a local identity, since they are created in line with schematized production requests so as to be accepted by different audiences throughout the world. That is why the media policy of the public broadcaster RTS has been oriented for years towards the rebroadcasting of old domestic series and the creation of new ones. Such a media policy affirms the justification of the notion cult television.

\subsection{Are these TV series cult television for young generations in Serbia? Results of the questionnaire}

In order to show how the young generations experienced the old socialist TV series, we distributed a questionnaire whose methodology was explained in the previous chapters. These are the results obtained. The sample consisted of 103 respondents between the ages of 15 and 27 . There were more female respondents - $(78.8 \%)$, and fewer male respondents - $(28.2 \%)$. When answering the question: Do you feel any kind of connection with the former Yugoslavia? just over half of the respondents said they did not (52.4\%). In addition, $(20.4 \%)$ of them gave an affirmative answer; almost the same number of respondents could not determine their connection with the former Yugoslavia (19.4\%), while (7.8\%) did not know the answer. Regarding the statement To what extent do you agree that we are still nostalgic for the former Yugoslavia even though it has not existed for a long time - the majority mostly agree (34\%). The answers to the question if they watched the reruns of former Yugoslavia TV series on public television were very diverse: $(32 \%)$ of the respondents watch them, (34\%) do not, and (34\%) occasionally watch them. The same happened regarding the question if they watched these TV series online: $(50.5 \%)$ of them watch them online, while $(49.5 \%)$ do not. The distribution of answers based on the Likert scale with regard to the question To what extent do you agree with the statement? I prefer to watch the domestic $T V$ series on public television (reruns) because I like them more than the foreign TV shows (American, Turkish, Indian, Latin American/Spanish is very interesting and is shown in the graph below. 


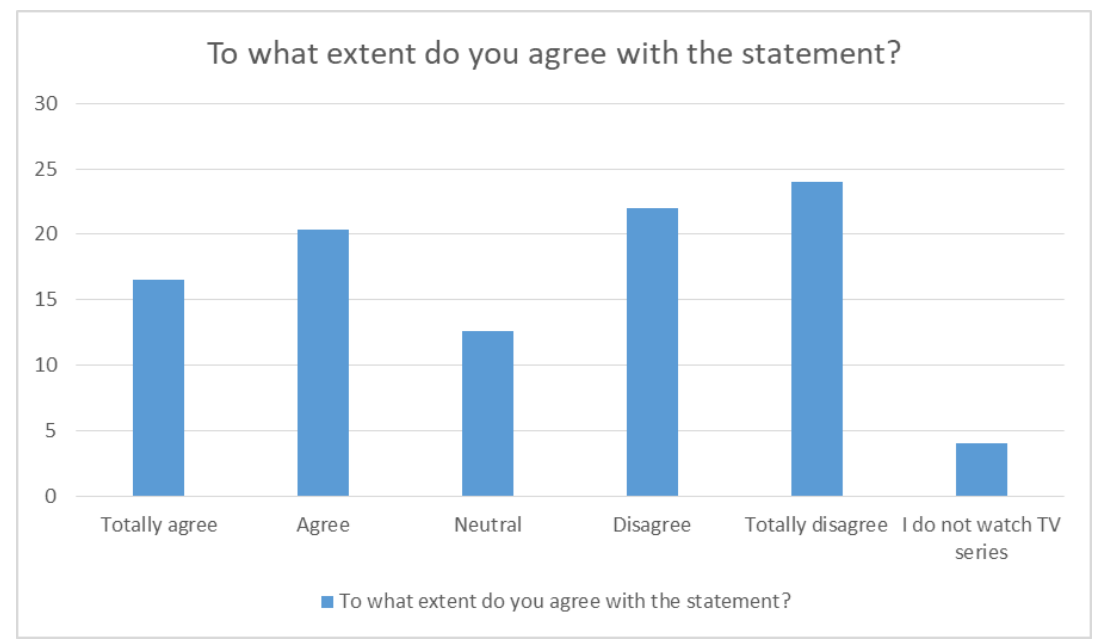

Graph 1 Viewing preferences

The TV series that are least known to young audiences are More than a Game $(29.1 \%)$ and Citizens of the Village Lug (71.8\%). However, the set of questions related to the cultural values of these TV series brings very positive views and opinions. Moreover, (33\%) of respondents mostly agree that Yugoslav TV series are an important part of the cultural memory of generations born after the breakup of Yugoslavia, while (38.8\%) of them completely agree with this statement. Young people believe that what makes the Yugoslav TV series authentic is humor (44\%); the vigor and strong opposition of the characters (20.4\%); the identical social practices - little has changed in Serbia (19.4\%); the constant production of Yugoslavism and Yugoslav discourses - Tito, partisans, fraternity and unity (15.5\%); everything else (music, costumes, decor and more) is represented at a much smaller percentage. What is very significant in our research is the emphasis on cult television, thus, in line with that, $(66 \%)$ of the respondents believe that these TV series can be considered cult shows, $(25 \%)$ are undecided, $(8 \%)$ do not know, and only (1\%) think the opposite.

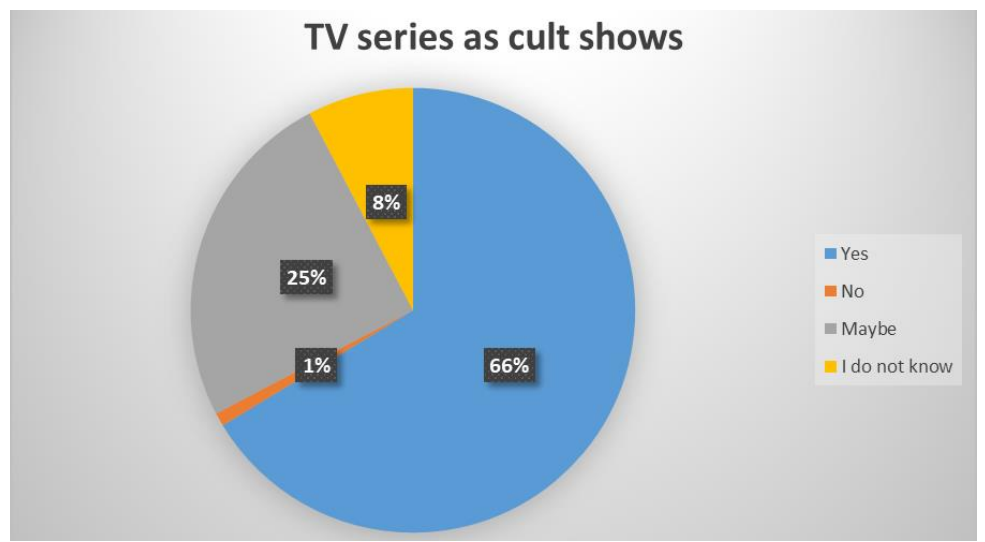

Graph 2 Cult TV 
One respondent said: "A lot of TV series from this era resemble each other, but it can be a bit "charming". Humor and dialogue often go beyond generations, which is not the case with recent TV series, music and other media" $\left(\mathrm{R} 71, \mathrm{M}^{2}\right)$.

One female respondent concludes the following: "These TV series are cult television as they are and I would not change anything, because due to the way they were filmed (including the selection of actors, the scenery, the music, etc.), they make us feel empathy and recall a maybe happier time when people were more attached to each other than they are now. The only thing I would change is the gap between the reruns - it should be longer, for example 3 or 4 years." (R30, F)

When comparing the old with the new TV series, another female respondent concluded, "Maybe the recording quality was even better than it is today, compared to the technology capabilities. They are excellent given the time when they were filmed" (R91, F).

With regard to the TV series selected by the respondents as the greatest of all time, a respondent said: "I am not a fan of shootings and violence, but I still believe that the TV series The Sacrificed is very good." (R59, F). Moreover, the respondents in general gave high grades to the selected TV series. Therefore, young generations who are less able to have cultural memory due to the passage of time, still remember the TV series that have often been rerun on public television. This is very important since the commercialization of the media and also the introduction of cable operators since the 1990s onwards increased the number of television channels, which made the Radio Television of Serbia only one among countless other TV channels. And more importantly, part of this generation watches the old TV series on the Internet. Even though they are aware that there are many excellent quality foreign TV series, they respect the cultural values of the TV series once produced by TV Belgrade and clearly distinguish the elements that make these TV series cult shows. By engaging in cult television, they participate in preserving the Yugonostalgia.

\section{CONCLUSION}

To analyze all the aspects of the mediatization of cultural memory related to Yugoslavia, it would take much more time and many more authors. Therefore, this could be a successful future project. This paper has named one type of cultural memory manifestation and preservation. Such form of cultural memory preservation shows a paradigm shift from an abstract thing to the field of emotional and fictional attributes of the values of Socialist Yugoslavia by post-socialist young generations. Since the time they were initially broadcast, the TV series of Television Belgrade have had a large audience that remains faithful to this television genre even in periods of increasingly strong domination of foreign television programs. That loyalty can be interpreted through important concepts of identity, culture and resistance to the growing media globalization. Although the entire Yugoslav culture, including everyday life, not only shows its quality and reach, but also the intense overlap of different ideologies, it is very important to study the evolutionary stages, potentials and reaches of cultural memory from this distance in time. Moreover, it is necessary to recognize the close link which exists between cultural memory, everyday life and cultural heritage. Everything that previous generations did and created, which today represents a resource of inexhaustible symbolic meaning, has a special value for the present generations since it affects the formation of their identities. Although intended for a wide audience,

\footnotetext{
${ }^{2}$ The number of the respondent (R1-R103) and their gender (Male, Female).
} 
through specific genre conventions and in a complex social-political context, cult television participates in the formation of cultural identity and cultural memory of several generations. However, identity is not a stable category, but a concept and a narrative that changes. As Malrieu said several decades ago, it is a profound problem of our time (Malrieu 1982). Since the collective cultural identity of post-socialist generations is still manifested, built and constructed, its preservation is uncertain and questionable due to the ever-increasing distance of time from the Yugoslav era. However, this research shows that young generations remember the TV series that were often rerun and have an opinion about them. They value them as cult television and as part of the Yugoslav cultural memory. Although they belong to the digital generations, the patterns of transferring television discourses, their repetition, revitalization, and reinterpretation cause the concept of Yugonostalgia to still remain strong and persist even among these young post-socialist generations.

\section{Limitations and future prospects}

This is a topic that requires intensive audience research. In this paper, interviews were used only as a supplement to other research methods. To create a clear picture of how much cultural memory is mediated by television among the younger generations, a much larger project is needed on which a team of researchers would work.

\section{REFERENCES}

Assman, J. "Communicative and Cultural Memory". In Cultural Memory Studies. An International and Interdisciplinary Handbook, edited by A. Erll and A. Nünning, 109-118. Berlin, New York: 2008.

Bancroft, C. "Yugonostalgia: The Pain of the Present". Independent Study Project (ISP) Collection. 787, 2009, https://digitalcollections.sit.edu/isp_collection/787

Blitz, B. War and Change in the Balkans: Nationalism, Conflict and Cooperation. London: Cambridge University Press, 2006

Chushak, N. Yugonostalgic against All Odds: Nostalgia for Socialist Federal Republic of Yugoslavia among Young Leftist Activists in Contemporary Serbia (PhD thesis). The University of Melbourne, School of Social and Political Sciences, Faculty of Arts, 2013.

della Dora, V. "Engaging Sacred Space: Experiments in the Field". Journal of Geography in Higher Education 35, 2 (2011): 163-184. DOI: 10.1080/03098265.2010.523682

Deacon, D. and J. Stanyer. "Mediatization: Key Concept or Conceptual Bandwagon?". Media, Culture and Society 36, 7 (2014): 1-13. Retrieved from https://doi.org/10.1177/0163443714542218

Eliade, M. The Sacred and the Profane: The Nature of Religion. New York: Harcourt, 1959.

Eriksen, T. H. Ethnicity and Nationalism: Anthropological Perspectives. London: Pluto Press, 2002.

Gwenllian-Jones, S. Pearson, R. Cult Television. University of Minnesota Press, 2004.

Ifversen, J. "Text, Discourse, Concept: Approaches to Textual Analysis". Kontur 7 (2003): 60-69. http://kontur.au.dk/fileadmin/www.kontur.au.dk/OLD_ISSUES/pdf/kontur_07/jan_ifversen.pdf

Imre, A. TV Socialism. Duke University Press, 2016.

Josifović, S. i N. Senić. Pozicioniranost RTS-a u percepciji auditorijuma, Beograd: RTS, Centar za istraživanje javnog mnjenja, programa i auditorijuma, 2011.

Lavery, D. The Essential Cult TV Reader. University Press of Kentucky, 2010.

Luthar, B. and M. Pušnik. Remembering Utopia: The Culture of Everyday Life in Socialist Yugoslavia. New Academia Publishing, LLC, 2010.

Albvaš, M. "Kolektivno i istorijsko pamćenje”. Reč 56 (1999): 63-82.

Maksimović, M. "Unattainable Past, Unsatisfying Present - Yugonostalgia: An Omen of a better Future?". Nationalities Papers 45, 6 (2017): 1066-1081. DOI: 10.1080/00905992.2017.1312324

Malrieu, F. „Identitet: pojmovi i koncepcija”. Kultura 59 (1982): 19-36.

Mihelj, S. "Understanding Socialist Television: Concepts, Objects, Methods". VIEW - Journal of European Television History and Culture 3, 5 (2014): 7-16. https://www.viewjournal.eu/articles/10.18146/22130969.2014.jethc051/ 
Mihelj, S. Huxtable, S. From Media Systems to Media Cultures Understanding Socialist Television. Cambridge University Press, 2018.

Mustata, D. "Editorial". VIEW - Journal of European Television History and Culture 3, 5 (2014): 1-6. DOI: http://doi.org/10.18146/2213-0969.2014.jethc050

Nandy, A. "Memory work”. Inter-Asia Cultural Studies 16, 4 (2015): 598-606. DOI: 10.1080/14649373.2015.1103018

Nielsen Audience Measurement. Серијски играни програм на Првом и Другом програму РТС-а према пореклу продукције од 2003. до 2013.

Simeunović Bajić, N., L. Vesnić Alujević i A. Majdarević. „Televizijsko repriziranje kao moguća strategija kulturne politike i odgovor publike". U Kultura $i$ društveni razvoj, priredio Mirko Miletić. Beograd: Fakultet za kulturu i medije, 2012.

Simeunović Bajić, N. „TV Series Bolji život (1987-1991): View from the Future”. In Critical Reflections on Audience and Narrativity: New Connections, New Perspectives, edited bx B. Mitu, S. Branea, and V. Marinescu, 179-194. Hannover: Ibidem Verlag, 2014.

Simeunović Bajić, N. „Medijsko rekonstruisanje jugoslovenskog kulturnog nasleđa i kolektivnog pamćenja”: slučaj 'Dana mladosti'”. U Ogledi o jugoslovenskom kulturnom nasleđu, uredio Ivan Kovačević, 193-224. Beograd: SGC, Filozofski fakultet, 2012.

Simeunović Bajić, N. Domaće igrane TV serije u jugoslovenskoj i postjugoslovenskoj popularnoj kulturi (Disertacija). Beograd: Fakultet političkih nauka, 2015.

Simeunović Bajić, N. "Reprezentovanje urbanih heroja rata u popularnoj TV seriji Otpisani". Etnoantropološki problemi 11, 1 (2016): 48-61. DOI: https://doi.org/10.21301/EAP.V11I1.2

Simeunović Bajić, N., N. Senić and S. Josifović. „Kulturno-istorijski značaj Centra za istraživanje javnog mnjenja, programa i auditorijuma RTS: jugoslovenski i postjugoslovenski kontekst”. Godišnjak Fakulteta za kulturu i medije: komunikacije, mediji, kultura 5, 5 (2013): 449-466.

Simeunović Bajić, N. and M. Vujović. "Sacred Spaces of Mediatized Cultural Memory: Return to the Socialist Yugoslavia". In Communicative Space - Political Space, 11th Central and Eastern European Communication and Media Conference (Book of Abstracts), edited by G. Hajzer, et al. University of Szeged, 2018.

Soresku Marinković, A. S druge strane granice. Jugoslovenska televizija i druge uspomene iz svakodnevnog života Rumuna u Banatu, 2014, http://dais.sanu.ac.rs/123456789/5796

Spasić, I. "Jugoslavija kao mesto normalnog života: Sećanja običnih ljudi u Srbiji”. Sociologija 54, 4 (2012): 577-594.

Quigley, C. The Evolution of Civilizations: An Introduction to Historical Analysis. Indianapolis: Liberty Press, 1961

Volčić, Z. Neither East nor West: the past and present life of Yugoslav identity, CAS Working Paper Series, 2, 2009. Retrieved from http://www.cas.bg/uploads/files/Zala\%20Volcic.pdf

Vuković K. "Najbogatiji evropski TV arhiv". Standard, 2009. Retrieved from http://www.standardmagazin. com/tema.php?ID=2555

\section{TV series}

Đorđević, A. (director). (1974-1975). Otpisani. Beograd: CFS Košutnjak, TV Beograd.

Đorđević, A. (director). (1980). Vruć vetar. Beograd: TV Beograd.

Đukanović, M. (director). (1973). Kamiondžije. Beograd: CFS Košutnjak, TV Beograd.

Lazić, D. (director) (1972). Građani sela Luga. Beograd: TV Beograd.

Šotra, Z. (director) (1977). Više od igre. Beograd: TV Beograd.

\section{JAVNI MEDIJSKI SERVIS I POVRATAK U SOCIJALISTIČKU JUGOSLAVIJU: MEDIJATIZACIJA KULTURNOG PAMĆENJA POST-SOCIJALISTIČKIH GENERACIJA}

U radu se razmatraju četiri značajna koncepta i diskursa savremene srpske post-socijalističke kulture: 'sveti' prostor, kulturno pamćenje, medijatizacija i Jugoslavija. Kratak pregled protivurečnosti jugoslovenske istorije $i$ politike implicira širi opseg $i$ više tema istraživanja. Prekinute debate o pozitivnim i negativnim aspektima socijalističke Jugoslavije pružaju priliku da se ponovo razmotri nasleđe televizije $i$ kulturno pamćenje sa vremenske distance. Ovom prilikom razmatraju se dimenzije svojevrsnog svetog prostora u kulturnom pamćenju a to su zapravo mnogobrojne i stalne 
reprize na javnom medijskom servisu Srbije. Pre svega, istraživanje se fokusira na televizijske serije kao autentični TV žanr i kultni televizijski program. Ovaj rad pokazuje da veoma veliki broj repriza jugoslovenskih TV serija na javnom medijskom servisu doprinosi očuvanju kulturnog pamćenja kod pripadnika post-socijalističkih generacija i izgradnji distinktivnih obeležja lokalnog kulturnog identiteta.

Ključne reči: Jugoslavija, kulturno pamćenje, medijatizacija, TV reprize, sveti prostor. 